\title{
Analysis of Credit Risk, Intellectual Capital and Financial Performance of Listed Deposit Money Banks in Nigeria
}

\author{
Rislanudeen Muhammad \\ Bank of Industry-Nigeria
}

\begin{abstract}
This paper examined the effects of credit risk, intellectual capital as well as credit risk moderated by intellectual capital on financial performance of fifteen listed deposit money banks in Nigeria (DMBs) from 2007 to 2016. Data were sourced from annual reports of banks and Nigerian National Bureau of Statistics and analysed using Generalised Method of Moments (GMM). The study finds that credit risk index by loan loss ratio negatively affects financial performance of the sampled banks; while capital employed efficiency, loan loss provision moderated by intellectual capital, capital adequacy ratio, income and diversification have positive relationship with banks' financial performance. Thus, the study recommends that banks should strengthen their credit risk management culture to ensure prompt repayment of loans. The banks should operate within the required capital adequacy ratio to serve as buffer against loan loss provisions provided by the Central Bank of Nigeria. A strong credit risk management culture should be embedded within intellectual capital structure of banks, where all persons at all levels appreciate and understand the banks' risk management policies as well as strategies and incorporate same into decision-making and business processes.
\end{abstract}

KEYWORDS: Credit risk, Intellectual Capital, Financial Performance, Deposit Money Banks, GMM, Nigeria.

JEL Classification: G32, 034, G21, C33.

\subsection{INTRODUCTION}

The banking crisis of the 1990s as well as glaring weaknesses of Basel I accord made the Basel Committee on Banking Supervision (BCBS) to propose Basel II in 1998, which recognised both market, operational and credit risks with the aim of supporting stronger credit risk management practices. Initially published in June 2004, its full implementation in 2008 across major economies was distracted by the 20072008 World financial crisis, the worst crisis since the great depression that began in the early 1920s (Stiglitz, 2019) and climaxed in 1929 when the stock market in United States of America collapsed and banks failed.

The 2007-2008 financial crisis had shown that Basel II was not enough in dealing with the complicated challenges. At the beginning of the crisis, most Banks were found to have too much leverage and insufficient liquidity buffers as well as poor structure thereby leading to credit and liquidity risk. This led to an agreement on Basel III by the Basel committee members in November, 2010, with the ultimate objective of promoting leverage, capital, funding and liquidity. However, its full implementation, initially due for 2013 was changed to 2015, moved again to March 31, 2019 and now slated for January 1, 2022.

The impact of global financial crisis of 2008 alerted both the government and businesses in Nigeria on the importance of sound credit risk management practices. According to Sanusi
(2011), the eventual high magnitude level of Non-Performing Loans (NPLs) in banks was caused by poor corporate governance practices, non-adherence to credit risk management practices and lack of attention to changes in macroeconomic factors like interest rates and inflation rates. In order to improve on the framework for credit risk management, Nigeria, partly adopted Basel I accord and subsequently Basel II and Basel III accords, to strengthen the capital adequacy of banks, thereby mitigating credit risks, minimise the impact of unpredictable financial losses on banks as well as potential systemic crisis.

As part of its banking industry reforms, the $\mathrm{CBN}$ reviewed the universal banking model which permitted banks to act as financial supermarkets. However, the implementation of the universal banking model was characterised by inadequate capital and capacity to manage the wide range of businesses and products, excessive risk appetite and exposure particularly to affiliate transactions (contagion risk), weak group corporate governance, complexity and opaque structures and processes as well as inadequate regulatory/ supervisory capacity.

The new banking model which was aimed at addressing these weaknesses, categorised deposit money banks (DMBs) licensed to operate as regional, national or international, with their minimum capital requirements specified as N10 billion, N25 billion and N50 billion respectively. For the purpose of 
risk-based supervision, CBN classified DMBs into three: large, medium and small, with assets of N1 trillion and above, N501 billion to N999 billion as well as N500 billion and below respectively. Large banks, typically have foreign jurisdictions with branches off-shore as well as subsidiaries. Due to their importance to the economy in terms of the amount of capital, asset base, branch network, staff strength among others, they are classified as 'too big to fail' or 'systemically important' with a minimum capital adequacy ratio (CAR) requirement of $16 \%$, while the medium and small banks are required to have minimum CAR of $10 \%$. However, the maximum limit of NPLs ratio is $5 \%$ across all categories of DMBs in Nigeria.

The rapid technological change, growing financial engineering and innovations and increasingly sophisticated customers have shifted the base of competition for many businesses away from traditional physical and financial resources to the intellectual capital (IC) of organisations. The IC, such as knowledge, experience, processes and people, have become the core means of present and future wealth (Steward, 1997; and Petty \& Guthrie, 2000). Consequently, businesses began to embrace formalised approaches to manage and measure IC, with the underlying benefits of doing so including improved growth in businesses, enhanced financial performance as well as more effective strategic planning, leading to enhanced productivity. The intellectual capital, all things been equal, can determine the success or otherwise of an organisation compared to its competitors (ElBannany, 2008).

The success of credit risk management of banks depends in large part on the skill, knowledge, imaginative mind and professional experience of the bank employees in terms of proper identification and analysis of any possible threats to loans as well as mitigation and articulation of optimal credit administration strategies to avoid the loans getting bad with attendant consequences of provision and negative impact on CAR. On the other hand, structural capital comprising information systems, databases, copyrights and patents support human resources to produce new and better products and services to attract new customers and retain existing ones through relational capital (RC), to enable enhanced financial performance.

Moreover, various studies such as: Sampagnaro et al., (2015) and Fiordelisi et al., (2013) revealed that a bank can optimally compete by building effective and efficient bond with their customers as well as having stronger investments in soft information. On the other hand, Goh (2005) and Kamath $(2007$; 2015) observed that effective utilisation of IC is very valuable in attaining efficiency in banking. This underscores the imperative for efficient and effective management of IC by banks. However, effective and efficient credit risk management as well as customer relations by banks may only be possible when employees possess requisite knowledge and experience. Structural capital, human capital and relational capital are vital elements of IC and important in the process of credit risk management in banks. In addition, Kamath (2007), argued that the banking sector is ideal for IC research due in part, to availability of reliable data and the nature of banking business which is intellectually intensive. Also, banking staff are intellectually more homogeneous than staff in other sectors as argued by Kubo and Saka (2002).

Banks' financial performance can be evaluated based on either its financial ratios, CAMELS (Capital, Asset Quality, Management, Earnings, Liquidity and Sensitivity), parametric and non-parametric models (Stochastic Frontier analysis and Data Envelopment analysis) or Skandia's Navigator, Intangible Assets Monitor, Balanced Scorecard, Value-Added Intellectual Coefficient (VAIC), among others. Of course, none of them can alone give enough information about the financial status of a bank or its financial performance. They are however, important financial indicators that guide investors and managers while making policies and crafting strategies for their organisations.

Divergent results have been obtained from studies on how credit risk management affects financial performance. The mixed results were obtained even where the same proxy for financial performance were used (see: Bertin, Moya \& Perales, 2014; Yijun Zou, 2014; Menicucci \& Paolucci, 2016; Ara et al. 2009; Lalon, 2015; Muriithi, 2016; Boahene, Samuel \& Agye, 2012; Kwabena, 2014; and Musa, 2015). This lack of convergence implies that there is no consensus on the relationship between credit risk and financial performance.

In Nigeria, Ajayi and Ajayi (2017), Musa (2015), Marshal and Onyekachi (2014), Taiwo and Abayomi (2013), Oluwafemi et al. (2013), Ogboi and Unuafe (2013), Kolapo, Kolade and Ojo (2012), Owojori et al. (2011) and Kargi (2011) assessed the response of financial performance of Nigerian banks to credit risk. The common credit risk variables used in these studies include loan loss provision ratio, non-performing loan ratio and ratio of loans \& advances, control variables like capital adequacy ratio (CAR), size and diversification. Ordinary Least Square (OLS) and generalised least square (GLS) estimation methods were used in most of these studies. However, these studies, did not consider other important variables such as efficiency ratio, inflation rate risk and GDP growth. Methodologically, these studies were deficient as despite the dynamic nature of banks' financial performance dynamic model was not applied. None of these studies considered the moderating effects of intellectual capital on credit risk and financial performance of banks despite the increasing importance of intellectual capital in the banking industry.

This study differs from previous Nigerian studies, by using GMM in recognition of the dynamic nature of events in the banking sector, so as to examine the effect of immediate past financial performance on the current period. It is assumed that current period's financial performance is affected by information from the past period. Several studies employed GMM to identify factors that influence profitability of banks, 
such as Athanasoglou, Brissimis and Delis (2008) GMM Greece, Liu and Wilson (2010) for Japan and Dietrich and Wanzanried (2011) for Switzerland.

The study examined the effects of credit risk, intellectual capital as well as credit risk moderated by intellectual capital on financial performance of fifteen listed deposit money banks in Nigeria. The study also assess the effect of other banking industry indicators and some macroeconomic variables on the financial performance of listed banks in Nigeria using GMM.

The paper is as follows: following this introduction is section 2 which reviews literature and theoretical framework, section 3 is data and methodology, section 4 contains results interpretation, while Section 5 is conclusion and recommendations.

\subsection{LITERATURE REVIEW}

\subsection{Conceptualisation}

\subsubsection{Credit Risk Management}

Credit risk denotes a situation where a borrower is unable or unwilling to comply with a contractual obligation as at when due (Bessis, 2002; and Colquitt, 2007). Credit risk indicates the inability of a bank to receive due obligations in form of principal and interest from loans, guarantees or other commitments. Conford and Coyle (2000), defined credit risk as the possibility of depletion or outright loss from projected return on an investment. Although, credit risk in a bank may not be completely eliminated, it can be mitigated with a sound and well-articulated credit risk management policies. The board of directors of a bank are responsible for developing their credit risk policy which is to be aligned with their overall business strategy.

Banks mitigate credit risk through efficient credit risk management that involves a holistic credit risk analysis of the loans, security arrangement, loan portfolio diversification, pricing, repayment capacity and monitoring (Afriyie \& Akotey, 2013). Effective credit risk management by banks is underscored by the underlying importance of mitigating and or minimizing credit risks as well as its negative impact on financial performance.

According to Nijskens \& Wagner (2011), credit risk management requires risk identification, measurement, mitigations, monitoring and controlling of credit risks. Risk based supervision by central banks have played significant role in minimizing credit risk, especially NPLs and also ensuring sufficient capital adequacy.

An important aspect of risk management is enterprise risk management (ERM). This has gained more prominence globally after the 2007-2008 global financial crisis. Most rating agencies such as Moody, Fitch and Standard and Poor (S\&P's) use ERM as one of the main parameters for the assessment, measurement and control of various risk levels of financial institutions. In Nigeria, Augusto \& Co, Datapro and GCR (global rating), have been licensed by the CBN to provide credit rating services for DMBs.

\subsubsection{Intellectual Capital (IC)}

Although the increasing importance of IC in the global economy has attracted the attention of researchers, it has no universal definition. IC is defined as "non-financial assets of a company that are not reflected in the balance sheet" (Frykman and Tolleryd, 2010). Similarly, Martinez and Garcia-Meca (2005) view IC as "the knowledge, information, intellectual property and experience that can be put to use to create capital". Stewart \& Zadunaisky (1998), defined IC as the knowledge, information and intellectual property which has an impact on firm's wealth. Edvinsson and Malone (1997), defined IC as the value of organisational experience which is embedded in an organisation's process, course of actions, systems and corporate structures.

The value added intellectual coefficient (VAIC) is a method used to measure the value creation efficiency of a company by using its accounting-based figures (Pulic, 2000a). Companies with higher VAIC represent higher value creation in utilising available resources like IC and physical capital. Employees' expenses, according to Pulic (2000b), should be seen as investments rather than costs, as the knowledge held by these employees are the main source of value creation. The VAIC was employed to assess the effects of intellectual capital efficiency (ICE) on the financial performance of banks and non-banks (Chen et al., 2005). VAIC is basically an improved version of earlier IC financial measurement models (Skandia's Navigator, Balanced Scorecard and Intangible Assets Monitor). As a measure of intellectual capital, VAIC has several advantages as compared to other measures. It provides a standardised and consistent basis of measurement and computation of VAIC, based on audited financial statements which is authentic and verifiable (Pulic, 2000a). It produces quantifiable, objective and quantitative measurements without subjectivism.

Even though IC is essentially intangible in nature, it is an important strategic asset with capacity for generating superior and more potent value thereby leading to enhanced financial performance (Barney, 1991). IC consists mainly of three parts: structural capital (SC), human capital (HC) and relational capital (RC). The $\mathrm{HC}$ is the combined knowledge as well as capabilities of the company's individual employees. SC represents the knowledge embedded in technology, software, databases and structure. The SC consist of the structures that employees develop and put in place to allow for optimal productivity as well as innovation, while RC constitutes the knowledge entrenched in an organisation's relationship with customers (Edvinsson \& Malone, 1997; and Bontis, 1998).

\subsubsection{Financial Performance of Banks}

The assessment of financial performance of banks was extensively studied over several years (Maghyereh \& Awartani, 2014). Researchers have used different methods towards measuring the financial performance of banks such as financial ratios (Poudel, 2012; Oluwafemi et al., 2013; and Alzorqan, 2014); Capital, Asset quality, Management, 
Earnings, Liquidity and Sensitivity (CAMELS) analysis (Rozzani \& Rahman 2013; Soltani et al, 2013); the parametric techniques via Stochastic Frontier Analysis (SFA) (Fan \& Shaffer, 2004) and the non-parametric techniques via Data Envelopment Analysis (DEA) (Kao et al., 2011; Fernando \& Nimal, 2014; and Maghyereh \& Awartani, 2014). The financial ratios have been used as a measure of financial performance of banks in a large number of research studies (Naceur \& Kandil, 2009; and Alzorqan, 2014). The most common ratios used are Net Interest Margin (NIM), Return on Assets (ROA) and Return on Equity (ROE), (Ariffin \& Kassim, 2011; Aebi, Sabato \& Schmid, 2012; and Oluwafemi et al., 2013).

However, in this study ROA was used as a measure of financial performance largely due to availability of data. Moreover, the ROA indicates the level of net income generated by the bank and also determines how the assets utilized by banks generate profit over the years. The ranking of banks is usually based on the ROA ratio and total assets. As a general view, particularly in banking sector, ROA is known as good profitability multiplier because equity multiplier does not influence it (Saeed \& Zahid, 2016).

\subsection{Theoretical Literature}

Credit risk management is often analysed within the context of information asymmetry theory. Twin problems of adverse selection (risk assessment/screening) and moral hazard (monitoring) are critical in credit risk management. They usually impact on the credit risk ratios and thus affect the financial performance of banks. The relationship between IC and credit risk can be captured by the agency theory managers may maximize their own utility instead of enhancing shareholder value due to information asymmetry between the principals and agents. This creates agency conflicts and costs that affect financial performance of banks. Modern Portfolio theory can be applied to explain the problem of credit concentration risk that can adversely impact on financial performance of banks. The efficiency and effectiveness of banks' IC assets influences their financial performance. The resource-based theory reveals that intangible assets are central to the understanding of competitive advantage of organisations since they cannot easily be acquired or imitated, contrary to tangible assets. This theory emphasises the significance of IC in improving the financial performance of banks. Thus, the asymmetric performances between heterogeneous companies are very much likely driven by intangible strategic assets. In Signalling theory, voluntary corporate disclosure serves the purpose of informing investors and analysts about the firm's value and quality thereby getting assured of cogent and potentially sustainable financial performance of banks.

Therefore, this study would be based on the information asymmetry theory (Akerlof, 1970; Spence; 1973; Rothschild and Stiglitz, 1976; Mirrlees, 1999; Holmström, 1979; Grossman and Hart, 1983), Agency theory (Jensen and Meckling, 1976; Sappington, 1991; Hart, 1995), Modern
Portfolio theory (Markowitz, 1952; Tobin, 1958; Sharpe, 1964) and Resourced based theory (Wernerfelt, 1984; Barney, 1991).

\subsection{Empirical Literature}

Several studies have analysed how credit risk management affects financial performance of banks from different perspectives. Some studies observed inverse relationship between credit risk and banks' financial performance (see: Menicucci \& Paolucci, 2016; Tan, 2013; Al Karim et al., 2013; Lalon, 2015; Muteti, 2014; Awoke, 2014; Bizuayehu, 2015; Taiwo \& Abayomi, 2013; Oluwafemi et al., 2013; Muriithi et al., 2016; and Ajayi \& Ajayi, 2017), others found positive relationship (see: Boahene, Samuel \& Agye, 2012; Kwabena, 2014; Ogboi \& Unuafe, 2013; Marshal \& Onyekachi, 2014; Musa, 2015; and Osuka \& Amako, 2015). Since IC is an asset of a bank, its increase should raise the value of the bank as well. Yet empirical studies have yielded mixed results on the relationship between IC and financial performance of banks. For instance, Tiwari and Vidyarthi (2018), examined the impact of IC on corporate performance of 39 Indian listed banks from 1999 to 2015. Panel fixed effects technique was used and findings provided evidence of positive association between IC and financial performance of banks. However, only HC and SC have shown instances of statistically significant, positive linkage with banks' financial performance. The result also has indicated that the ICE of private sector banks are better than public sector banks.

Ajayi and Ajayi (2017) observed the response of financial performance to credit risk management of eight (8) DMBs in Nigeria from 2001-2015. Using panel regression for the study, Profit after tax (PAT) was employed as indicator for bank performance, while loan loss provision ratio (LLPR), non-performing loan ratio (NPLR), cost per loan ratio (CPLR) and loan to total asset ratio (LTAR) served as measures of credit risk management. The result of GLS fixed effect (FE) regression revealed that banks' profitability was negative but is not statistically influenced by NPLR, LLPR, CPLR and LTAR. The study concluded that Nigerian DMBs were characterised by high rate of NPLs consistent with the high growth rates of loans and advances.

Nawaz and Haniffa (2017), empirically examined the effect of IC on financial performance of 64 Islamic financial institutions (IFIs) operating in Asia, Europe and the MiddleEast from 2007 to 2011, while controlling for firm-specific variables. The VAIC methodology was applied to examine the effect of IC on financial performance and the POLS regression results indicate that VAIC is directly associated with accounting performance indexed as ROA.

Nadeem, Gan and Nguyen (2017), examined the dynamic relationship between IC and financial performance of 6,045 public listed firms in Brazil, Russia, India, China and South African (BRICS) from 2005 to 2014. The GMM results revealed that IC (human, structural and physical) is positively related to ROA. 
Muriithi et al., (2016) explored the impact of credit risk on 43 commercial banks' financial performance in Kenya from 2005 to 2014. Panel data techniques of random effects (RE), FE estimations and GMM were applied for the study and the findings indicate that market, liquidity, credit, and operational risks negatively affect return of equity (ROE).

Meles, Porzio, Sampagnaro, and Verdoliva (2016), examined the impact of ICE on performance of 5,749 commercial Banks in the United States of America from 2005 to 2012. Results found that IC directly affects banks' financial performance. Furthermore, Human Capital component of intellectual capital appeared to have larger effect compared to other components on the financial performance.

Bertin, Moya and Perales (2014), evaluated the determinants of bank performance in Latin America. Using the panel data system estimator version of the GMM and two-stage least squares method, the study conducted on 78 commercial banks from 1995 to 2010 observed that financial performance is directly related to banks' specific factors (size, service diversification, capital ratio) as well as macroeconomic factors (inflation, economic growth and bank concentration). The study revealed that financial performance is inversely associated with liquidity risk, credit risk and operational inefficiencies.

Yijun Zou (2014), examined profitability of 47 commercial banks in relation to their credit risk management in Europe from 2007 to 2012. The OLS regression results indicated that profitability of commercial banks is directly related credit risk management. Unlike CAR, NPLR as a proxy for credit risk management significantly 2effect both ROE and ROA as measures of financial performance.

Oluwafemi, et al. (2013), examined the relationship between risk management and financial performance of banks in Nigeria. The study conducted on 10 banks employed panel data estimation technique and obtained data from financial statement and annual report for 4 consecutive years. The paper found that risk management affect financial performance of banks, where doubtful loans and capital asset ratio were indirectly and directly related to financial performance respectively.

Tan (2013), examined the relationship between performance and competitive condition of 101 Chinese banks from 20032009. The GMM regression results revealed that Bank size, NPLR, taxation, liquidity risk, capitalisation, cost efficiency, labour productivity, banking sector development, stock market development, stock market volatility, inflation, GDP growth and money market rate, significantly affected Bank performance (ROA).

In general, Al-Tamimi (2010) classified the financial performance determining factors into two: bank-specific (also refer to as internal) and macroeconomic (external) factors. The internal (micro) factors are features that influence performance of individual bank. They are variables that are affected by the internal decisions of the bank. The external variables are industry-wide (Banking sector development, Stock market development and Stock market volatility) or country-wide factors (like Inflation rate risk, foreign exchange risk, interest rate risk and Growth Domestic Product), which are beyond the control of the bank and affect their financial performance.

In summary, there are three basic determinants of banks' financial performance used in previous studies, and these are; i) Bank- specific variables indexed by operational risk, liquidity risk, bank size, tax, efficiency ratio, labour productivity, deposit ratio and diversification; ii) Industryspecific variables indexed by stock market development, banking sector development and stock market volatility; and iii) macroeconomic variables proxied by inflation rate risk, interest rate risk, foreign exchange rate risk and Gross Domestic Product (GDP). This study adopted these basic determinants in specifying the independent and control variables.

\subsection{DATA AND METHODOLOGY}

\subsection{Data}

Data were collected from annual reports and accounts of 15 selected DMBs that operated in Nigeria over the period 2007 to 2016, been the post banking sector reform period. Thus, the financial performance (FP) is indexed by return on assets (ROA), while credit risk is indexed by non-performing loans ratio (NPL), loan loss provision ratio (LLP), loan ratio (LOR) and cost per loan ratio (CLR). The control variables include bank-specific: operational risk (CAR), bank size (BAS), efficiency ratio (EFR) and diversification (DIV) as well as macroeconomic variables: inflation rate (INF) and GDP growth rate (GDP). IC components: structural capital efficiency (SCE), human capital efficiency (HCE) and capital employed efficiency (CEE) indexed by VAIC was used as moderator. All data were generated from audited annual accounts of the sampled banks except INF and GDP that were obtained from the Nigerian National Bureau of Statistics (NBS). 
"Analysis of Credit Risk, Intellectual Capital and Financial Performance of Listed Deposit Money Banks in Nigeria"

Table 1: Data Sources and Measurement

\begin{tabular}{|c|c|c|c|c|c|}
\hline Variables & Acronym & Description & Source & Measurement & $\begin{array}{c}\text { A Priori } \\
\text { Expectation }\end{array}$ \\
\hline $\begin{array}{c}\text { Financial } \\
\text { Performance }\end{array}$ & ROA & $\begin{array}{l}\text { Return on } \\
\text { Assets }\end{array}$ & $\begin{array}{l}\text { Annual } \\
\text { report } \\
\text { of banks }\end{array}$ & $\begin{array}{l}\text { Annual profit before interest \& tax to total assets as used by } \\
\text { Tan and Floros (2012), Bertin, Moya \& Perales (2014); Lalon } \\
\text { (2015), Menicucci and Paolucci (2016) }\end{array}$ & \\
\hline \multirow{4}{*}{ Credit Risk } & NPL & $\begin{array}{l}\text { Non- } \\
\text { performing } \\
\text { loans ratio }\end{array}$ & $\begin{array}{l}\text { Annual } \\
\text { report } \\
\text { of banks }\end{array}$ & $\begin{array}{l}\text { Annual non-performing loans to total loan as used by Tan and } \\
\text { Floros (2012), Boahene, Samuel \& Agye (2012), Bertin, Moya \& } \\
\text { Perales, (2014), Menicucci and Paolucci (2016), Sobhy and } \\
\text { Megeid (2017), Ajayi \& Ajayi (2017) }\end{array}$ & - \\
\hline & LLP & $\begin{array}{l}\text { Loan Loss } \\
\text { Provision ratio }\end{array}$ & $\begin{array}{l}\text { Annual } \\
\text { report } \\
\text { of banks }\end{array}$ & $\begin{array}{l}\text { Annual loan loss provision to total loans as used by Tan (2013), } \\
\text { Kwabena (2014), Lalon (2015), Ishtiaq (2015), Ajayi \& Ajayi } \\
\text { (2017) }\end{array}$ & - \\
\hline & LOR & Loan ratio & $\begin{array}{l}\text { Annual } \\
\text { report } \\
\text { of banks }\end{array}$ & $\begin{array}{l}\text { Annual total loans to total assets as used by Tan and Floros } \\
\text { (2012), Tan (2013), Menicucci and Paolucci (2016), Sobhy and } \\
\text { Megeid (2017), Ajayi \& Ajayi (2017) }\end{array}$ & + \\
\hline & CLR & $\begin{array}{l}\text { Cost per loan } \\
\text { ratio }\end{array}$ & $\begin{array}{l}\text { Annual } \\
\text { report } \\
\text { of banks }\end{array}$ & $\begin{array}{l}\text { Annual total operating cost to total loans as used by Awoke } \\
\text { (2014), Ajayi \& Ajayi (2017) }\end{array}$ & - \\
\hline \multirow{3}{*}{$\begin{array}{l}\text { Intellectual } \\
\text { Capital } \\
\text { Efficiency }\end{array}$} & HCE & $\begin{array}{l}\text { Human Capital } \\
\text { Efficiency }\end{array}$ & $\begin{array}{l}\text { Annual } \\
\text { report } \\
\text { of banks }\end{array}$ & $\begin{array}{l}\text { Annual value added to human capital as used by Carrington } \\
\text { (2013), Purohit and Tandon (2015), Berzkalne and Zelgalve } \\
\text { (2014), Ghosh and Maji (2014), Meles, Porzio, Sampagnaro and } \\
\text { Verdoliva (2016) }\end{array}$ & + \\
\hline & SCE & $\begin{array}{l}\text { Structural } \\
\text { Capital } \\
\text { Efficiency }\end{array}$ & $\begin{array}{l}\text { Annual } \\
\text { report } \\
\text { of banks }\end{array}$ & $\begin{array}{l}\text { Annual structural capital to value added as used by Carrington } \\
\text { (2013), Berzkalne and Zelgalve (2014), Purohit and Tandon } \\
\text { (2015), Ghosh and Maji (2014), Meles, Porzio, Sampagnaro, } \\
\text { and Verdoliva (2016) }\end{array}$ & + \\
\hline & CEE & $\begin{array}{l}\text { Capital } \\
\text { Employed } \\
\text { Efficiency }\end{array}$ & $\begin{array}{l}\text { Annual } \\
\text { report } \\
\text { of banks }\end{array}$ & $\begin{array}{l}\text { Annual value added to capital employed as used by Carrington } \\
\text { (2013), Berzkalne and Zelgalve (2014), Purohit and Tandon } \\
\text { (2015), Meles, Porzio, Sampagnaro and Verdoliva (2016) }\end{array}$ & + \\
\hline Moderator & VAIC & $\begin{array}{l}\text { Value added } \\
\text { intellectual } \\
\text { coefficient }\end{array}$ & $\begin{array}{l}\text { Annual } \\
\text { report } \\
\text { of banks }\end{array}$ & $\begin{array}{l}\text { Annual sum of Human Capital Efficiency, Structural Capital } \\
\text { Efficiency and Capital Employed Efficiency as used by } \\
\text { Carrington (2013), Berzkalne and Zelgalve (2014), Purohit and } \\
\text { Tandon (2015), Meles, Porzio, Sampagnaro, and Verdoliva } \\
\text { (2016) }\end{array}$ & + \\
\hline \multirow{6}{*}{$\begin{array}{l}\text { Control } \\
\text { Variables }\end{array}$} & CAR & $\begin{array}{l}\text { Operational } \\
\text { risk (CAR) }\end{array}$ & $\begin{array}{l}\text { Annual } \\
\text { report } \\
\text { of Banks }\end{array}$ & $\begin{array}{l}\text { Annual total equity to total assets as used by Tan and Floros } \\
\text { (2012), Tan (2013), Goddard et al., (2008), Bertin, Moya \& } \\
\text { Perales (2014), Lalon (2015), Menicucci and Paolucci (2016) }\end{array}$ & + \\
\hline & BAS & Bank size & $\begin{array}{l}\text { Annual } \\
\text { report } \\
\text { of banks }\end{array}$ & $\begin{array}{l}\text { Log of annual total assets of the bank as used by Tan and } \\
\text { Floros (2012), Boahene, Samuel \& Agye (2012), Ishtiaq (2015), } \\
\text { Menicucci and Paolucci (2016) }\end{array}$ & + \\
\hline & EFR & Efficiency ratio & $\begin{array}{l}\text { Annual } \\
\text { report } \\
\text { of banks }\end{array}$ & $\begin{array}{l}\text { Annual total expenses to total assets as used by Tan and Floros } \\
\text { (2012), Tan (2013) }\end{array}$ & + \\
\hline & DIV & Diversification & $\begin{array}{l}\text { Annual } \\
\text { report } \\
\text { of banks }\end{array}$ & $\begin{array}{l}\text { Annual non-interest income to total assets as used by Bertin, } \\
\text { Moya \& Perales (2014). }\end{array}$ & + \\
\hline & INF & $\begin{array}{l}\text { Inflation Rate } \\
\text { Risk }\end{array}$ & NBS & Annual inflation rate as used by Tan (2013) and Lake (2013) & - \\
\hline & GDP & GDP growth & NBS & Annual GDP growth rate as used by Tan (2013) and Lake (2013) & + \\
\hline
\end{tabular}

Source: compiled by the author, 2019.

\subsection{Model Specification}

The model of Muriithi et al. (2016) was adapted and is specified in equation 1 below;

$R O A_{i, t}=\beta_{0}+\beta_{1} C R W A R_{i, t}+\beta_{2} L L P R_{i, t}+\beta_{3} A Q R_{i, t}+$

$\beta_{4} L A R_{i, t}+a_{i}+\mu_{i, t}$
From equation 1, $R O A_{i, t}$ refers to performance of bank $i$ at time t. $\beta_{0}$ is intercept, $\beta_{1}$ to $\beta_{4}$ are coefficients of the explanatory variables. $C R W A R_{i, t}, L P R_{i, t}, A Q R_{i, t}$ and $L A R_{i, t}$ represent capital to risk weighted assets ratio of bank, loss provision ratio, Assets quality ratio and loan and advances 
ratio of bank $i$ at time $t$ respectively. The $a_{i}$ is the bank specific effect that is assumed to be normally distributed with a constant variance and $\mu_{i, t}$ is the error term.

However, the model of Muriithi et al. (2016) was modified to moderate for credit risk using VAIC and to include variables like return on assets, net interest margin, loan loss provision, loan ratio, cost per loan ratio, diversification, inflation and GDP growth rate. The ICE indexed by VAIC was used to moderate the impact of credit risk on financial performance of listed DMBs in Nigeria. Researchers like Chen et al. (2005), Shiu (2006), Ghosh and Mondal (2009), Ting and Lean (2009) as well as Clarke et al. (2011), have measured the ICE using VAIC model.

Therefore, to determine the impact of IC on the association between credit risk and financial performance of 15 selected DMBs in Nigeria, we applied difference GMM regression methods to estimate the short run relationships between the variables, following Tan and Floros (2012) and Tan (2013) for China; Bertin, Moya and Perales (2014) for Latin America; and Muriithi et al. (2016) for Kenya. The adapted model is as specified below:

$\mathrm{FP}_{\mathrm{i}, \mathrm{t}}=\mathrm{f}$ (Credit risk variables, VAIC, Control variables)

The model is specified as follows;

$F P_{i, t}=\beta_{0}+\alpha F P_{i, t-1}+\beta_{1} N P L_{i, t}+\beta_{2} L L P_{i, t}+\beta_{3} L O R_{i, t}+$ $\beta_{4} C L R_{i, t}+\beta_{5} H C E_{i, t}+\beta_{6} S C E_{i, t}+\beta_{7} C E E_{i, t}+$ $\beta_{8} M N P L_{i, t}+\beta_{9} M L L P_{i, t}+\beta_{10} M L O R_{i, t}+\beta_{11} M C L R_{i, t}+$ $\beta_{12} C A R_{i, t}+\beta_{13} B A S_{i, t}+\beta_{14} E F R_{i, t}+\beta_{15} D I V_{i, t}+$ $\beta_{16} I N F_{i, t}+\beta_{17} G D P_{i, t}+\eta_{i}+\eta_{t}+\mu_{i, t}$
A priori: $\beta_{1}, \beta_{2}, \beta_{3}, \beta_{4}, \beta_{16}<0 ; \alpha, \beta_{5}, \beta_{6}, \beta_{7}, \beta_{8}, \beta_{9}, \beta_{10}, \beta_{11}, \beta_{12}, \beta_{13}$, $\beta_{14}, \beta_{15}, \beta_{17}>0$;

All variables are as earlier defined, while moderated NPL (MNPL), moderated LLP (MLLP), moderated LOR (MLOR) and moderated CLR (MCLR) are computed as NPL*VAIC, LLP*VAIC, LOR*VAIC, and CLR*VAIC respectively, indicating the interaction between credit risk represented by NPL, LLP, LOR and CLR respectively with the IC represented by VAIC. The $\beta_{17}$ is expected to be negative or positive depending on the efficiency of the managers. The $\eta_{i}$ and $\eta_{t}$ are Fixed individual effect and time effect of banks respectively. The individual effect refers to a set of specific characteristics of each Bank that are constant over time. The time effect includes the macroeconomic factors that have an impact on all the Banks simultaneously. The $\mu_{i t}$ is the error term. The $\alpha$ is the parameter of the lagged financial performance.

\subsection{Estimation procedure}

In order to achieve the objective of the study, Generalised Method of Moments (GMM) econometrics techniques was used. This is because relevant estimators such as Pooled Ordinary Least Square (POLS) and Generalised Least Square (GLS) estimators do not provide a consistent estimate due to the presence of a lagged dependent variable amongst the regressors. One-step difference GMM estimator with oneyear time lag is used for the study.

\subsection{RESULTS AND DISCUSSION}

\subsection{Descriptive Statistics and Correlation Analysis}

Table 2: Descriptive Statistics

\begin{tabular}{|c|c|c|c|c|c|c|c|c|c|c|c|c|c|c|c|c|c|c|}
\hline & & & & & CLIT & & & & & & & & & & EFR & & INF & GDP \\
\hline & & & & 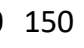 & 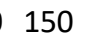 & & & & & & & & & 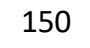 & 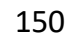 & & 0 & ) \\
\hline & & 0. & 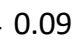 & 90 & +0 & 25 & & & & & & & 4 & 4 & & & & 10 \\
\hline & & & & & & (6) & & & & & & & & & & & & \\
\hline & 4 & 40 & & 0 & & & 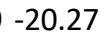 & 2 & & & & & & & & & 05 & \\
\hline & 7 & 0 & 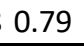 & 90 & 50 & 76.89 & & 3 & & & 24.34 & & & 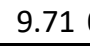 & 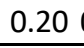 & & 016 & 0 \\
\hline
\end{tabular}

Source: Researcher's Computation using STATA 13.

Table 2 shows the average ROA of the sampled banks during the period is $1 \%$. It indicates weak return attributable to shareholders of banks. The mean and standard deviation of NPL ratio are 0.14 and 0.20 respectively, indicating high volatility in credit risk. The mean of NPL of $14 \%$ indicates that for every NGN1.00 of loans and advances granted by a bank, NGN0.14k is non-performing. The average LLP of Nigerian banks was $9 \%$. This shows that on average, banks in Nigeria set aside $9 \%$ of loans and advances as provision for bad loans. The LOR indicates that on average, the total loans and advances of Nigerian banks constitutes $44 \%$ of their total assets. The LOR vary between $16 \%$ to $85 \%$ among the banks. However, the average CLR shows that total operating cost of the banks constitute $14 \%$ of their total loans and advances.
The three components of VAIC (HCE, SCE, CEE) have respective mean value of $3.25,0.36$ and 0.38 as shown in Table 1. From this, it is apparent that human capital is most effective in the matter of value creation than either capital employed or structural capital during the study period. The average HCE shows that the human capital of Nigerian banks including employees' productivity, capabilities, abilities, knowledge, skills, experience, values, attitudes, aptitudes, know-how, individual relationships, creativity, education, qualifications, motivation, commitment, loyalty, interactions, expertise, proactive leadership abilities, flexibility, learning capacity, behaviour and risk-taking propensity contributed $81.5 \%$ to the value of the banks during the study period. 
The average SCE indicate that structural capital of the banks including its procedures, policies, databases, routines, hardware, organisational culture, processes as well as the technology used in the bank contributed only $9 \%$ to the value of the banks. The average CEE which comprises relationships of the organisation with the external environment such as suppliers, customers, clients, government, competitors and community as well as the image of organisation, reputation of products and satisfaction of clients contributed $9.5 \%$ of the banks. The average CAR indicates that the equity capital of Nigerian banks amounted to $14 \%$ of their total assets.
The EFR shows that $6 \%$ of the banks' total assets constitutes the total expenses incurred each year by the banks. The average DIV reveals that the income generated by Nigerian banks from other sources amounted to $4 \%$ of their total assets. The mean INF and GDP indicate that the average inflation rate and GDP in Nigerian economy was $11 \%$ and $6 \%$ respectively within the study period.

Table 3 presents Spearman correlation for the two indices of FP and the explanatory variables. The result of Skewness and Kurtosis normality test (Jacque-Bera Test) suggests that the variables are not normally distributed, hence the use of Spearman correlation instead of Pearson correlation.

Table: 3:Spearman Correlation

\begin{tabular}{c|ccccccccccccccccc}
\hline Variable & NPL & LLP & LOR & CLR & HCE & SCE & CEE & MNPL & MLLP & MLOR & MCLR & CAR & BAS & EFR & DN & INF & GDP \\
\hline ROA & -0.31 & -0.32 & -0.12 & -0.17 & 0.85 & 0.51 & 0.36 & 0.21 & 0.29 & 0.56 & 0.58 & 0.35 & 0.18 & -0.36 & 0.06 & -0.14 & 0.08 \\
\hline
\end{tabular}

Source: Researcher's Computation using STATA 13 based on data collected (2007-2016)

From Table 3, as expected the ROA is negatively related to credit risk variables. This means that the lower the NPL, LLP, LOR and CLR, the higher will be the ROA of banks in Nigeria. On the other hand, strong and positive relationship exist between ROA and IC indexed by HCE, SCE and CEE. This implies that banks that have strong and efficient IC tend to generate higher ROA.
The credit risk moderated by IC measured by MNPL, MLLP, MLOR and MCLR appeared to be positively related to ROA. This implies that IC impact positively on the credit risk of the banks. Positive relationship exists between CAR, BAS, DIV and GDP with ROA with correlation coefficient of $0.35,0.18$, 0.06 and 0.08 respectively. Finally, negative relationship exists between EFR, INF with ROA with correlation coefficient value of -0.36 and -0.14 respectively.

\subsection{Estimation Results}

Table 4: DGMM Estimation

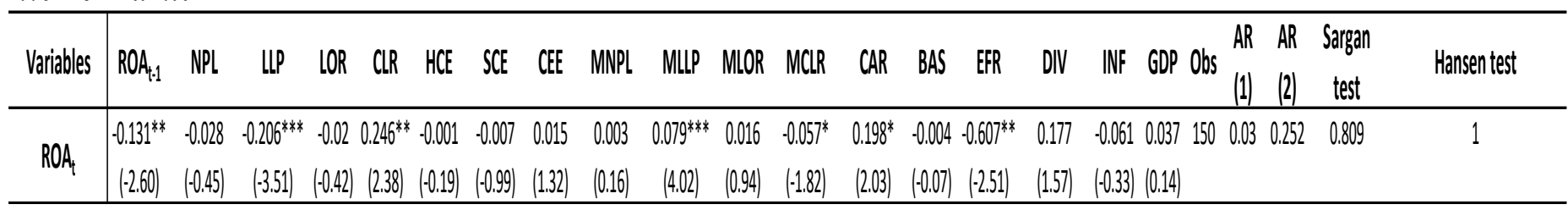

Source: Researcher's Computation using STATA 13. Note, ***, ** and * indicate 1\%, 5\% and 10\% significant levels respectively. The t-value is presented in parenthesis while the other figures represent the coefficients.

Table 4 present the one-step difference-GMM estimates of the model specified in equation 2 . The lagged ROA $\left(\mathrm{ROA}_{\mathrm{t}-1}\right)$ is negative and statistically significant at $5 \%$, thus confirms the dynamic nature of the model. It reveals that a percentage increase in the previous year's ROA is associated with $13 \%$ decrease in the current year's ROA.

The NPL was found to be negative but statistically insignificant. Similar result was obtained by Musa (2015), Muriithi et al. (2016) as well as Ajayi and Ajayi (2017). However, it contradicts the findings of Awoke (2014), Yijun Zou (2014), Lalon (2015), Ishtiaq (2015) and Bizuayehu (2015) that found a significant, negative effect of NPL on ROA of banks. The LLP is found to have inverse relationship with banks' ROA in Nigeria at $1 \%$. This result is supported by Sufian and Chong (2008), Liu and Wilson (2010), Ishtiaq (2015) as well as Menicucci and Paolucci (2016), but contradicts the findings of Kwabena (2014) and Lalon (2015), who found a significant positive effect of LLP on ROA.
Similar to NPL, LOR is found to be negative but statistically insignificant in the different time horizons. This finding is supported by Menicucci and Paolucci (2016) as well as Ajayi and Ajayi (2017). However, the finding is inconsistent with that of Awoke (2014), who found a significant negative association between LOR and ROA.

The CLR was found to be positive and statistically significant with ROA at $5 \%$. This finding tallies with those of Boahene, Samuel and Agye (2012) and Awoke (2014), but contradicts that of Ajayi and Ajayi (2017). The result shows that among the variables used to index credit risk, only LLP conforms with our a priori expectation and is statistically significant. This indicates that financial performance of listed Nigerian banks is influenced by credit risk measured using LLP in the different periods.

The HCE was negative and statistically insignificant with ROA.This means that a percentage increase in HCE do not significantly increase or decrease ROA of banks in Nigeria. 
This means that, banks in Nigeria were not utilising their human capital investments effectively. This finding is supported by Chan (2009), Yu et al. (2010), Mehralian et al. (2012) as well as Purohit and Tandon (2015). It however, contradicts the work of Ting and Lean (2009), Clarke et al. (2011), Carrington (2013), Nimtrakoon (2015), Meles, Porzio, Sampagnaro and Verdoliva (2016), Sardo and Serrasqueiro (2016) as well as Nawaz and Haniffa (2017), who reported a significant positive impact of human capital efficiency on financial performance. It also contradicts the findings of Bontis (1998), Shiu (2006), Chan (2009) as well as Ghosh and Maji (2014), who found a significantly negative impact of HCE on stock market performance.

The SCE was negative and statistically insignificant. This means that, banks in Nigeria were not utilising their structural capital investments effectively. This finding is consistent with the works of Phusavat et al. (2011), Sardo and Serrasqueiro (2016), but contradicts that of Chan (2009), Yu et al. (2010) and Carrington (2013) who found a significant positive impact of SCE on ROA.

Similarly, CEE was positive but statistically insignificant, this is in line with the work of Chan (2009), Yu et al. (2010), Komnenic and Pokrajcic (2012), Carrington (2013), Nimtrakoon (2015), Sardo and Serrasqueiro (2016) as well as Nawaz and Haniffa (2017). It however contradicts the findings of Ting and Lean (2009), Gigante and Previati (2011) as well as Purohit and Tandon (2015), who established an insignificant positive effect of CEE on ROA. Thus, CEE does not significantly influence ROA of banks in Nigeria.

The MNPL which stands as the value of moderated NPL is positive but statistically insignificant. However, the moderated LLP (MLLP) is positive and statistically significant at $1 \%$. The moderated CLR (MCLR) is statistically significant but negatively related with ROA. The results indicate that among the variables that were used to measure the impact of IC on credit risk management, only MLLP and MLOR appear to have the expected sign and is statistically significant. Thus, IC impact on the credit risk which subsequently affects financial performance of listed Nigerian banks in Nigeria.

The CAR was positive and statistically significant at $10 \%$ significance level. This finding is similar to those of Sensarma and Jayadev (2009), Lake (2013), Muteti (2014), Bertin, Moya and Perales (2014), Lalon (2015), Ishtiaq (2015) and Musa (2015), but contradicts the findings of Hosna, Manzura \& Juanjuan (2009) as well as Yijun Zou (2014), who found a statistically negative and insignificant association between CAR and ROA. However, Bizuayehu (2015), found a statistically negative and significant association between CAR and ROA. Thus, CAR has positive and significant impact on ROA.

BAS was negative and statistically insignificant. The result tallies with those of Scholtens (2000), Vander (2002), Yu et. al (2010), Komnenic and Pokrajcic, (2012), Tan (2013) and Nimtrakoon (2015), but contradicts those of Boahene,
Samuel and Agye (2012), Lake (2013), Bertin, Moya and Perales (2014), Awoke (2014), Musa (2015), Bizuayehu (2015), Menicucci and Paolucci (2016), Sardo and Serrasqueiro (2016), Muriithi et al. (2016) as well as Nawaz and Haniffa (2017), who found positive and significant association between BAS and ROA.

EFR was negative and statistically significant with ROA at $5 \%$ significance level. This finding is supported by Bourke (1989) and Jiang et al. (2003), but contradicts that of Molyneux and Thornton (1992), Guru et al., (2002) and Naceur (2003), who found significant positive relationship between profitability and expenses.

The result provides evidence that DIV has positive but has insignificant impact on ROA. This result is supported by Bertin, Moya and Perales (2014), but contradicts that of Demirguc-Kunt and Huizinga (1999).

INF has negative and insignificant impact on ROA. This result is supported by the findings of Abreu and Mendes (2002), Lake (2013) and Bizuayehu (2015), but against the conclusion of Guru et al. (2002), Jiang et al. (2003), Kosmidou et. al (2008), Sufian and Habibullah (2009), Garcia-Herrero et al. (2009), Kapur and Gualu (2011), Damena (2011), Tan and Floros (2012), Tan (2013) as well as Bertin, Moya and Perales (2014), who reported positive and significant association between inflation and profitability.

GDP has positive and insignificant effect on ROA. The finding is inconsistent with Sufian (2010), Tan and Floros (2012) and Tan (2013), who found negative and significant impact of GDP on ROA.

Post estimation tests were conducted to ensure the reliability and validity of the instruments used in the study. In order to ascertain the validity of the instruments used in the GMM estimation, Arrelano \& Bond (1991), autocorrelation test and Hansen J-statistic are presented in Table 4. Arrelano and Bond autocorrelation test revealed that there was first-order but no second order autocorrelation. This is evidenced by AR (2) 0.252. Hansen J Statistic revealed that the instruments are valid with a value of 1.000 .

\subsection{CONCLUSIONS AND RECOMMENDATIONS}

The study concludes that credit risk measured as LLP ratio reduces the financial performance of listed deposit money banks in Nigeria. The increased exposure to credit risk reduces ROA as well as financial performance of banks. The credit risk reflects health of loan portfolio which affects banks' financial performance. Similarly, it was also observed that credit risk moderated by intellectual capital affects financial performance of listed Nigerian DMBs. Other variables that influence financial performance of listed Nigerian DMBs include CAR and DIV. The finding is in line with modern portfolio theory which advocate diversification and avoiding credit risk concentration.

Therefore, the study recommends that in order to ensure the competitiveness, soundness, profitability and financial 
stability of the Nigerian banking industry, Nigerian DMBs should strengthen their credit risk management culture including credit policies, assessment, analysis, monitoring, control, approval and administration to ensure prompt repayment of loans. Management of banks should also ensure that policy on loan approvals are strictly adhered, to reduce both LLP ratio, improve the asset quality management and consequently increase profitability. $\mathrm{CBN}$ policies should also be further strengthened to ensure sound and well-articulated credit risk management policies. CBN should ensure that DMBs define and strictly adhere to their risk appetite and tolerance limits as well as risk acceptance criteria within the context of their specific defined strategic plans. To enhance interaction of IC on credit risk, Banks should increase investment in $\mathrm{HC}$ and improve on its management via training, recruitment, promotion, adequate compensation, motivation and placement of employees. Banks should also have an effective management of information technology infrastructure to enable efficient, cost effective service delivery to customers for optimum financial performance. To ensure prudent lending, stability and soundness of banking business, banks should maintain higher capital ratio, specifically in line with $\mathrm{CBN}$ requirements of having minimum CAR of $10 \%$ and $16 \%$ for tier 2 banks and tier 1 (systemically important) banks respectively. The banks should also continue to diversify their sources of income in order to mitigate risk.

\section{REFERENCES}

1. Abreu, M. \& Mendes, V. (2002), "Commercial bank interest margins and profitability: evidence from E.U. Countries", University of Porto Working paper Series, No. 122, available at:

www.iefs.org.uk/Papers/Abreu.pdf

2. Aebi, V., Sabato, G. \& Schmid, M., (2012). "Risk management, corporate governance, and bank performance in the financial crisis". Journal of Banking and Finance, 36(12), pp. 3213-3226.

3. Afriyie, H.O. \& Akotey, J.O., (2013). Credit risk management and profitability of rural banks in the Brong Ahafo region of Ghana. European Journal of Business and Management, 5(24), pp.24-33.

4. Ajayi, L. B., \& Ajayi F. I., (2017). "Effects of Credit Risk Management on Performance of Deposit Money Banks in Nigeria". International Journal of Research in Management \& Business Studies (IJRMBS 2017), 4(3).

5. Akerlof, G. (1970). "The market for lemons: Quality uncertainty and the market mechanism". The Quarterly Journal of Economics, 89, 488-500.

6. AlKarim, R., \& Alam, T. (2013). “An evaluation of financial performance of private commercial banks in Bangladesh: ratio analysis". Journal of Business Studies Quarterly, 5(2), 65.
7. Al-Tamimi, H., (2010). "Factors influencing performance of the UAE Islamic and conventional national banks". Global Journal of Business Research, 4(2), pp.1-9.

8. Alzorqan, S.T., (2014). "Bank liquidity risk and performance: an empirical study of the banking system in Jordan". Research Journal of Finance and Accounting, 5(12), pp.155-164

9. Ara, H., Bakaeva, M., \& Sun, J. (2009). "Credit risk management and profitability in deposit money banks in Sweden". M.Sc. Thesis in Accounting. University of Gothenburg, School of Business, Economics and Law.

10. Arellano, M. \& Bond, S. (1991), "Some tests of specification for panel data: Monte Carlo evidence and an application to employment equations", Review of Economic Studies, Vol. 58 No. 2, pp. 277 297.

11. Ariffin, N.M. \& Kassim, S.H., (2011). "Risk management practices and financial performance of Islamic banks: Malaysian evidence", 8th International Conference on Islamic Economics and Finance. 19-21 December 2011. Doha: Qatar.

12. Athanasoglou, P.P., Brissimis, S.N. \& Delis, M.D. (2008). "Bank-Specific, Industry-Specific and Macroeconomic Determinants of Bank Profitability". Journal of International Financial Markets, Institutions and Money, 18(2), 121-136.

13. Awoke, E. T., (2014). "Impact of credit risk on the performance of commercial banks in Ethiopia". Published MBA thesis. ST. Mary's University, Ethiopia.

14. Barney, J. B., (1991), "Firm Resources and Sustained Competitive Advantage", Journal of Management, 17(1), 99-120.

15. Bertin, M. J., Moya, J, M., \& Perales A. R., (2014) "Determinants of bank performance: evidence for Latin America", Academia Revista Latinoamericana de Administración, 27(2), 164-182, https://doi.org/10.1108/ARLA-04-2013-0030, Downloaded on (21 January 2018).

16. Berzkalne, I., Zelgalve, E. (2014) "Intellectual Capital and Company Value" Procedia - Social and Behavioral Sciences, 110(24), 887-896.

17. Bessis, J., (2002). Risk management in Banking, 2nd edn, John Wiley \& Sons, Inc, England.

18. Bizuayehu, M. (2015), "The Impact of Credit Risk on Financial Performance of Banks in Ethiopia". Published M.Sc. Thesis in Accounting and Finance. Addis Ababa University, Addis Ababa-Ethiopia.

19. Boahene, S. H., Samuel, J. D., \& Agyei, K., (2012). Credit Risk and Profitability of Selected Banks in Ghana, Research Journal of Finance and Accounting, 3(7), 1697-2222. 
20. Bontis, N. (1998). Intellectual capital: an exploratory study that develops measures and models. Management decision, 36(2), 63-76.

21. Bourke, P. (1989). Concentration and other determinants of bank profitability in Europe, North America and Australia. Journal of Banking and Finance, 13, 65-79.

22. Carrington, D., (2013). Intellectual Capital and Its Influence on the Financial Performance of Companies in Under Developed Capital Markets: The Case of the Caribbean, University of the West Indies.

23. Chan, K. H. (2009). Impact of intellectual capital on organizational performance: An empirical study of companies in the Hang Seng Index (Part 1). The Learning Organization, 16(1), 4-21.

24. Chen, M C, Cheng S J \& Hwang Y. (2005), “An Empirical Investigation of the Relationship Between Intellectual Capital and Firm's Market Value and Financial Performance", Journal of Intellectual Capital, Vol. 6, No. 2, pp.159-176.

25. Clarke, M., Seng D. \& Whiting R (2011), "Intellectual Capital and Firm Performance in Australia”, Journal of Intellectual Capital, Vol. 12, No. 4, pp. 505-530.

26. Colquitt, J. (2007). Credit Risk Management: How to Avoid Lending Disasters \& Maximize Earnings. 3rd Edition. McGraw-Hill. USA.

27. Conford, A \& Coyle (2000), "The Basel Committee's Proposals for Revised Capital Standards: Rationale, Design and Possible Incidence, G-24 Discussion Paper Series", United Nations, No.3, May.

28. Damena, H.B. (2011). Determinants of commercial banks profitability: an empirical study on Ethiopian commercial banks $^{\text {ee }}$, M.Sc. project paper, Addis Ababa University, Addis Ababa-Ethiopia.

29. Demirguc-Kunt, A. \& Huizinga, H. (1999). Determinants of Commercial Bank Interest Margins and Profitability: Some International Evidence. World Bank Economic Review, 13(2), 379-408.

30. Dietrich, A. and Wanzenried, G. (2011), "Determinants of bank profitability before and during the crisis: evidence from Switzerland", Journal of International Financial Markets, Institutions and Money, Vol. 21 No. 3, pp. 307-327.

31. Edvinsson, L, \& Malone, M. S. (1997). Intellectual Capital: Realizing Your Company's True Value by Finding Its Hidden Brainpower. HarperCollins Publishers, New York, NY.

32. El-Bannany, M. (2008), "A study of determinants of intellectual capital performance in banks: the UK case", Journal of Intellectual Capital, Vol. 9 No. 3 , pp. 487-498.
33. Fan, L. \& Shaffer, S., (2004). Efficiency versus risk in large domestic US banks. Managerial Finance, 30(9), pp.1-19.

34. Fernando, J.M.R. \& Nimal, P.D., (2014). "Does Risk Management Effect on Bank Efficiency?" An analysis of Sri Lankan banking sector. International Journal of Management and Sustainability, 3(2), pp.97-110.

35. Fiordelisi, F., Monferrà, S., \& Sampagnaro, G. (2013). Relationship lending and credit quality. Journal of Financial Services Research 46(3), 295 315

36. Frykman, D., \& Tolleryd, J. (2010). "Corporate Valuation (2nd ed.)". London: Prentice Hall.

37. Garcia-Herrero, A., Gavila, S. and Santabarbara, D. (2009), "What explains the low profitability of Chinese banks?", Journal of Banking and Finance, 33 (11), 2080-2092.

38. Ghosh, S \& Mondal A (2009), "Indian Software and Pharmaceutical Sector IC and Financial Performance”, Journal of Intellectual Capital, Vol. 10, No. 3, pp. 369-388.

39. Ghosh, S., K., Maji, S. (2014) "The Impact of Intellectual Capital on Bank Risk: Evidence from Indian Banking Sector". The IUP Journal of Financial Risk Management, Vol. XI, No. 3, September 2014, pp. 18-38.

40. Gigante, G. \& Previati, D.(2011), “A knowledgeoriented approach to the investigation of Italian banks performances", International Journal of Economics and Finance, 3 (5), 12-23.

41. Goddard, J., McKillop, D. \& Wilson, J. (2008), “The diversification and financial performance of US credit unions", Journal of Banking \& Finance, 32( 9), 1836.

42. Goh, P. (2005). Intellectual capital performance of commercial banks in Malaysia. Journal of Intellectual Capital 6(3), 385-96.

43. Grossman, S. and O. Hart (1983). "An analysis of the principal-agent problem". Econometrica, 51: 7 45.

44. Gujarati, D. (2003). "Basic Econometrics". London: McGraw-Hill.

45. Guru, B., Staunton, J. \& Balashanmugam, B. (2002). "Determinants of Commercial Bank Profitability in Malaysia". Paper presented at the 12th Annual Australian Finance and Banking Conference, Sydney, Australia.

46. Hart, S. L., (1995), "A Natural-Resource-Based View of the Firm". The Academy of Management Review, 20(4), 986-1014

47. Holmström, B. (1979). Moral Hazard and observability. Bell Journal of Economics, 10, 74-91.

48. Hosna, A., Manzura, B. \& Juanjuan, S. (2009). "Credit Risk Management and Profitability in 
Commercial Banks in Sweden". School of Business, Economics and Law, Gothenburg University.

49. Ishtiaq, M. (2015). "Risk Management in Banks: Determination of Practices and Relationship with Performance". PhD Economics Thesis. University of Bedfordshire, Luton-England.

50. Jensen, M. \& Meckling, C (1976). "Theory of the firm: managerial behavior, agency costs and ownership". Journal of Financial Economics, 3, 305-360.

51. Jiang, G., Tang, N., Law, E. \& Size, A. (2003). "Determinants of Bank Profitability in Hong Kong". Hong Kong Monetary Authority Quarterly Bulletin, September, 5-14.

52. Kamath, G. B. (2007), "The Intellectual Capital Performance of the Indian Banking Sector", Journal of Intellectual Capital, 8(1), 96-123.

53. Kamath, G. B. (2015), "Impact of Intellectual Capital on Financial Performance and Market Valuation of Firms in India", International Letters of Social and Humanistic Sciences, (48), 107-122.

54. Kapur, D \& Gualu, K A (2011). What drives the performance of commercial banks in Ethiopia? " International Journal of Research in Commerce \& Management, 2.

55. Kargi, H.S. (2011). "Credit Risk and the Performance of Nigerian Banks", Ahmadu Bello University, Zaria.

56. Kao, M., Lin, C., Hsu, P. \& Chen, Y., (2011). "Impact of the financial crisis and risk management on performance of financial holding companies in Taiwan". World Academy of Science, Engineering and Technology, 50, pp. 413-417.

57. Kolapo, T.F. Kolade, A.R., \& Ojo, O.M. (2012). "Credit risk and commercial banks" performances in Nigeria: a panel model approach", Australian journal of business and management research, 2(2),31-38.

58. Komnenic, B. Pokrajčić, D. (2012) "Intellectual capital and corporate performance of MNCs in Serbia", Journal of Intellectual Capital, 13(1), 106119.

59. Kosmidou, K., Tanna, S. and Pasiouras, F. (2008), "Determinants of profitability of domestic UK commercial banks: panel evidence from the period 1995-2002", Economics, Finance and Accounting Applied Research, Working paper, Series No. RP084), 1-27.

60. Kubo, I. and Saka, A. (2002) "An inquiry into the motivations of knowledge workers in the Japanese financial industry", Journal of Knowledge Management, Vol. 6 Issue: 3, pp.262-271, https://doi.org/10.1108/13673270210434368

61. Kwabena, A. B. M., (2014). "Credit Risk Management in Financial Institutions: A Case Study of Ghana Commercial Bank Limited". Research Journal of Finance and Accounting, 2222-2847.

62. Lake, E. (2013). "Financial Risks and Profitability of Commercial Banks in Ethiopia". Published Doctoral dissertation in Accounting and Finance. Addis Ababa University, Addis Ababa-Ethiopia.

63. Lalon, R. M., (2015). "Credit Risk Management (CRM) Practices in Commercial Banks of Bangladesh: "A Study on Basic Bank Ltd.". International Journal of Economics, Finance and Management Sciences, 3(2), 78-90.

64. Liu, H. \& Wilson, J. (2010). "The profitability of banks in Japan". Applied Financial Economics, 20(24), 1851-1866.

65. Maghyereh, A.I. \& Awartani, B., (2014). "The effect of market structure, regulation, and risk on banks efficiency". Journal of Economic Studies, 41(3), pp.405-430.

66. Markowitz, H. M. (1952). "Portfolio selection". Journal of Finance, 7(1), 77-91.

67. Marshal, I., \& Onyekachi, O. (2014). "Credit Risk and Performance of Selected Deposit Money Banks in Nigeria: An Empirical Investigation". European Journal of Humanities and Social Sciences, 31(1).

68. Martinez, I., \& Garcia-Meca, E. (2005). "Assessing the quality of disclosure on intangibles in the Spanish capital market”. European Business Review 17(4): 305-313.

69. Mehralian, G., Rasekh, H. R., Akhavan, P., \& Sadeh, M. R. (2012). "The Impact of Intellectual Capital Efficiency on Market Value: An Empirical Study from Iranian Pharmaceutical Companies". Iranian Journal of Pharmaceutical Research, 11, 195-207.

70. Meles, A., Porzio, C., Sampagnaro, G., \& Verdoliva, V. (2016). "The impact of the Intellectual Capital Efficiency on Commercial Banks Performance: Evidence from the US". Journal of Multinational Financial Management.

71. Menicucci, E., \& Paolucci, G. (2016), "The determinants of bank profitability: empirical evidence from European banking sector", Journal of Financial Reporting and Accounting, 14 (1), 86-115

72. Mirrless, J.A. (1999). "The theory of moral hazard and unobservable behaviour: Part I", Review of Economic Studies, 66, 3-21.

73. Molyneux, P. \& Thornton, J. (1992). "Determinants of European bank profitability: A Note". Journal of Banking and Finance, 16(6), 1173-1178.

74. Muriithi, J. G., Waweru, K. M., Muturi, W. M. (2016) "Effect of Credit Risk on Financial Performance of Commercial Banks Kenya", Journal of Economics and Finance, 7(4),72-83.

75. Musa, H. M. (2015). "Determinants of Financial Performance of Listed Mega Banks in Nigeria". 
Published M. Sc. Thesis in Accounting. Ahmadu Bello University Zaria, Kaduna-Nigeria.

76. Muteti, S. R. (2014). "Relationship between financial risk management and financial performance of 43 commercial banks in Kenya". MBA project. School of Business, University of Nairobi Kenya.

77. Naceur, S. B. (2003). "The Determinants of the Tunisian Banking Industry Profitability: Panel Evidence". Available at http://www.mafhoum.com/press6.

78. Naceur, S.B. \& Kandil, M., (2009). "The impact of capital requirements on banks cost of intermediation and performance: the case of Egypt". Journal of Economics and Business, 61(1), pp.70-89.

79. Nadeem, M., Gan, C., \& Nguyen, C. (2017) "Does intellectual capital efficiency improve firm performance in BRICS economies? A dynamic panel estimation", Measuring Business Excellence, 21(1), 65-85.

80. Nawaz, T., \& Haniffa,R., (2017) "Determinants of financial performance of Islamic banks: an intellectual capital perspective", Journal of Islamic Accounting and Business Research, 8(2), 130-142

81. Nimtrakoon, S., (2015) "The relationship between intellectual capital, firms' market value and financial performance: Empirical evidence from the ASEAN", Journal of Intellectual Capital, 16(3), $587-618$

82. Nijskens, R., \& Wagner, W. (2011). "Credit risk activities and systemic risk: how banks became less risky individually but posed greater risks to the financial system at the same time". Journal of Banking \& Finance, 35(6), 1391-1398

83. Ogboi, C. \& Unuafe O. K., (2013). "Impact of Credit Risk Management and Capital Adequacy on the Financial Performance of Commercial Banks in Nigeria". Journal of Emerging Issues in Economics, Finance and Banking ISSN: 2306- 367X, 2(3).

84. Oluwafemi, A.S., Adebisi, A.N.I., Simeon, O. \& Olawale, O., (2013). "Risk management and financial performance of banks in Nigeria". IOSR Journal of Business and Management, 14(6), pp.5256.

85. Osuka, B. \& Amako, J. (2015). "Credit Management in Nigeria Deposit Money Banks (2003-2013) (A Study of Selected Deposit Money Banks)". International Research Journal of Education and Innovation (IRJEI), 1(3), 66 - 103.

86. Owojori, A.A., I.R. Akintoye \& F.A. Adidu, (2011). "The challenge of risk management in Nigerian banks in the post consolidation era". Journal of Accounting and Taxation, 3(2): 23-31.

87. Petty, R. \& Guthrie J. (2000). "Intellectual Capital Literature Review: Measurement, Reporting and
Management”. Journal of Intellectual Capital Vol 1 No.2: 155-176.

88. Phusavat, K., Comepa, N., Sitko-Lutek, A. \& Boon Ooi, K. (2011), "Interrelationship between intellectual capital and performance", Industrial Management \& Data Systems, Vol. 111 No. 6, pp. 810-829.

89. Pulic, A. (2000a), "VAIC: An Accounting Tool for IC Management", International Journal of Technology Management, Vol. 20, Nos. 5/6/7/8, pp. 545-55.

90. Pulic, A. (2000b), "MVA and VAIC Analysis of Randomly Selected Companies from FTSE 250", available at vaic-on.net/downloads/ftse 30 .

91. Poudel, R.P.S. (2012). "The impact of credit risk management on financial performance of commercial banks in Nepal". International Journal of Arts and Commerce, 1(5),9-15.

92. Purohit, H., \& Tandon, K., (2015). "Intellectual Capital, Financial Performance and Market Valuation: A Study on IT and Pharmaceutical Companies in India". The IUP Journal of Knowledge Management, XIII(2).

93. Rothschild, M. and J.E. Stiglitz (1976). "Equilibrium in competitive insurance markets: An essay in the economics of imperfect information". The Quarterly Journal of Economics, 80, 629-49.

94. Rozzani, N. \& Rahman, R.A, (2013). "Camels and performance evaluation of banks in Malaysia: conventional versus Islamic”. Journal of Islamic Finance and Business Research, 2(1), pp.36-45.

95. Saeed, M. \& Zahid, N. (2016). "The impact of credit risk on profitability of the commercial banks". Journal of Business and Financial Affairs, 5(2), 1-7.

96. Sampagnaro, G., Meles, A., \& Verdoliva, V. (2015). "Monitoring in small business lending: how to observe the unobservable". Journal of Financial Research 38(4), 495-510.

97. Sanusi, S. L. (2011), "Global financial meltdown and the reforms in the Nigerian banking sector", CBN Journal of Applied Statistics, 2(1), 93-108

98. Sappington, D. E M., (1991), "Incentives in Principal-Agent Relationship", Journal of economic perspectives, 5(2), 45-66.

99. Sardo, F., \& Serrasqueiro, Z., (2016). "Intellectual Capital and Financial Performance Considering the Crisis Period: A European Empirical Study University of Beira Interior", Covilhã, Portugal.

100.Scholtens, B. (2000), "Competition, growth and performance in the banking industry", Department of Finance Working Paper, University of Groningen, Groningen, February.

101.Sensarma, R., \& Jayadev, M., (2009) "Are bank stocks sensitive to risk management?", The Journal of Risk Finance, 10(1),7-22, 
102.Sharpe, W. F., (1964), "Capital Asset Prices: A theory of Market Equilibrium under Conditions of Risk". The Journal of Finance, 19(3).

103. Shiu, H. (2006). "The Application of the ValueAdded Intellectual Coefficient to Measure Corporate Performance: Evidence from Technological Firms". International Journal of Management, 23, 356-365.

104.Sobhy, N., \& Megeid,A., (2017) "Liquidity risk management: conventional versus Islamic banking system in Egypt", Journal of Islamic Accounting and Business Research, 8(1), 100-128

105.Soltani, M., Esmaili, M., Hassan, M. \& Karami, H., (2013). "Evaluating the performance of public and private banks and providing suggestions for improving the performance"

106.Spence, A.M. (1973), “Job market signalling”, Quarterly Journal of Economics, 87(3), 35-74.

107.Steward, T.A. (1997). "Intellectual Capital; The New Wealth of Organization". New York: Doubleday.

108. Stewart, T. A. \& Zadunaisky, D. (1998). "La nueva riqueza de las organizaciones: El capital intellectual”. Ediciones Granica SA.

109.Stiglitz, J. E. (2019). "People, Power and Profits: Progressive Capitalism for an Age of Discontent". W.W. Norton and co. New York.

110.Sufian, F. \& Chong, R.R. (2008), "Determinants of bank profitability in a developing economy: empirical evidence from the Philippines", Asian Academy of Management Journal of Accounting and Finance, 4(2), 91-112.

111.Sufian, F. \& Habibullah, M.S. (2009), "Bank specific and macroeconomic determinants of bank profitability: Empirical evidence from the China banking sector", Frontiers of Economics in China, 4(2), 274-291.

112.Sufian, F. (2010). "Financial depression and the profitability of the banking sector of the Republic of Korea: Panel Evidence on Bank-specific and Macroeconomic Determinants". Asia-Pacific Development Journal, 17(2), 65-92.

113.Taiwo, A. M., \& Abayomi, S. T. (2013). "Credit management spur higher profitability? Evidence from Nigerian banking sector". Journal of Applied Economics and Business, 1(2), 46-53.

114.Tan, Y. A. \& Floros, Y., (2012) "Stock Market Volatility and Bank Performance in China", Studies in Economics and Finance, 29(3), 211-228.

115.Tan, Y. (2013). "Essays on the analysis of performance and competitive condition in the Chinese banking industry". Published PhD Thesis in Economics. University of Portsmouth, England.

116.Ting, I.W.K. \& Lean, H.H. (2009), "Intellectual capital performance of financial institutions in
Malaysia”, Journal of Intellectual Capital, Vol. 10 No. 4, pp. 588-599.

117.Tiwari, R., \& Vidyarthi, H. (2018) "Intellectual capital and corporate performance: a case of Indian banks", Journal of Accounting in Emerging Economies, 8(1),84-105.

118. Tobin, J., (1958), "Liquidity Preference as Behavior Towards Risk", The review of economic studies, 25(2),66-86.

119. Vander V. R. (2002), "Cost and profit dynamics in financial conglomerates and universal banks in Europe", Journal of Money, Credit and Banking, 34(1), 254-282.

120.Wernerfelt, B. (1984), "A resource-based view of the firm", Strategic Management Journal, 5 (2), 171-180.

121. Yijun Zou, F. L., (2014). "The Impact of Credit Risk Management on Profitability of Commercial Banks: A study of Europe". PhD Thesis submitted to the Umea School of Business and Economics. Umea School of Business and Economics.

122.Yu, K.Y., Ng, H.T., Wong, W.K., Chu, S.K.W. \& Chan, K.H. (2010). "An empirical study of the impact of intellectual capital performance on business performance". The 7th International Conference on Intellectual Capital, Knowledge Management \& Organizational Learning, The Hong Kong Polytechnic University, Hong Kong. 